\title{
PENGARUH KONSUMSI SARI KURMA PADA AKHIR KEHAMILAN TERHADAP KEMAJUAN PERSALINAN KALA I DAN JUMLAH PERDARAHAN SAAT PERSALINAN PADA PRIMIPARA DI WILAYAH KERJA PUSKESMAS KLATEN SELATAN
}

\author{
Suroso, Paryono \\ Kementerian Kesehatan Politeknik Kesehatan Surakarta Jurusan Kebidanan
}

\begin{abstract}
Mother Maternity needed drinks and foods that contain lots of sugar elements, this is because the amount of contraction of the muscles of the uterus when it will remove the baby, even more so if it takes a long time. Purpose of this study was to determine the effect of the consumption of palm juice at the end of pregnancy to the first stage of labor progress and the amount of bleeding during childbirth. The design of this study using a quasi-experimental design with the design of static comparation group, sampling technique using purposive sampling approach, analysis of data Bivariate statistical tests using independent sample t-test. Hypothesis test results with respect to the progress of the first stage of labor is obtained t count -3.234 while t table at dk $n-2$ (58) was 2,002 so that Ho refused because -3.234> 2.002 means "no influence between the consumption of palm juice regularly in late pregnancy with progress first stage of labor in primiparous in the BPM area of South Klaten Klaten district. On the amount of bleeding obtained $t$ count -3.131 while $t$ table at $d k n-2$ (58) was 2,002 so that Ho refused because -3.131> 2.002 means "no influence between the consumption of palm juice regularly in late pregnancy with bleeding amount of labor. In conclusion, there is the influence of the consumption of palm juice regularly in late pregnancy with bleeding amount of labor.
\end{abstract}

Keywords: Palm Juice, Duration Of Labor, The Progress Of Labor, Childbirth Bleeding

Ibu Bersalin sangat membutuhkan minuman dan makanan yang kaya akan unsur gula, hal ini karena banyaknya kontraksi otot-otot rahim ketika akan mengeluarkan bayi, terlebih lagi apabila hal itu membutuhkan waktu yang lama. Tujuan Penelitian ini untuk mengetahui pengaruh konsumsi sari kurma pada akhir masa kehamilan terhadap kemajuan persalinan kala I dan jumlah perdarahan saat persalinan. Rancangan Penelitian ini menggunakan quasi eksperimen dengan rancangan desain static group comparation, Teknik pengambilan sampel menggunakan pendekatan secara purposive sampling, analisis data secara Bivariat mengunakan uji statistik Independent Sample ttest. Hasil uji hipotesis berkenaan dengan kemajuan persalinan kala I didapatkan $\mathrm{t}$ hitung -3,234 sedangkan t tabel pada dk n-2 (58) adalah 2,002 sehingga Ho ditolak karena $-3,234>2,002$ artinya "ada pengaruh antara konsumsi sari kurma secara teratur pada akhir kehamilan dengan kemajuan persalinan kala I pada primipara di BPM wilayah Klaten Selatan Kabupaten Klaten. Pada jumlah perdarahan didapatkan t hitung -3,131 sedangkan t tabel pada dk n-2 (58) adalah 2,002 sehingga Ho ditolak karena $3,131>2,002$ artinya "ada pengaruh antara konsumsi sari kurma secara teratur pada 
akhir kehamilan dengan jumlah perdarahan persalinan. Simpulan, ada pengaruh antara konsumsi sari kurma secara teratur pada akhir kehamilan dengan jumlah perdarahan persalinan.

Kata Kunci : Sari Kurma, Lama Persalinan, Kemajuan Persalinan, Perdarahan Persalinan

\section{PENDAHULUAN}

Persalinan dimulai dengan proses membuka dan menipisnya serviks, dan janin turun ke dalam jalan lahir. Kelahiran adalah proses dimana janin dan ketuban didorong keluar melalui jalan lahir (Saifuddin, 2006).

Proses dinamik dari persalinan meliputi empat komponen yang saling berkaitan yang mempengaruhi baik mulainya dan kemajuan persalinan. Empat komponen ini adalah passanger (janin), passage (pelvis ibu), power (kontraksi uterus), dan psikis (status emosi ibu). Bila persalinan dimulai, interaksi antara passanger, passage, power, dan psikis harus sinkron untuk terjadinya kelahiran pervaginam spontan (Walsh, 2007).

Kemajuan persalinan pada kala I fase aktif merupakan saat yang paling melelahkan, berat, dan kebanyakan ibu mulai merasakan sakit atau nyeri, dalam fase ini kebanyakan ibu merasakan sakit yang hebat karena kegiatan rahim mulai lebih aktif. Pada fase ini, dibutuhkan kontraksi (power) yang adekuat untuk dapat memulai persalinan. Melemahnya kontraksi rahim atau kontraksi inadekuat ini merupakan penyebab terbanyak terjadinya partus lama (Kumarawati, 2010).

Banyak upaya untuk mengefektifkan kontraksi (power) antara lain; teknik ambulasi, perubahan posisi, mengosongkan kandung kemih, stimulasi putting, dan pemberian nutrisi serta mengurangi stressor dan kelelahan ibu (Kumarawati, 2010). Salah satu upaya yaitu dengan pemberian nutrisi yang baik, baik itu diberikan saat persalinan maupun sebelum persalinan.

Perempuan hamil yang akan melahirkan sangat membutuhkan minuman dan makanan yang kaya akan unsur gula, hal ini karena banyaknya kontraksi otot-otot rahim ketika akan mengeluarkan bayi, terlebih lagi apabila hal itu membutuhkan waktu yang lama. Kandungan gula, vitamin B1, dan zat besi sangat membantu untuk mengontrol laju gerak rahim dan menambah masa sistole (kontraksi jantung ketika darah dipompa ke pembuluh nadi). Sedangkan pada buah kurma, selain kedua kandungan tersebut, terdapat kandungan hormone potuchin yang berfungsi untuk mengikat rahim dan otot rahim sehingga dapat membantu mengurangi pendarahan pasca melahirkan. Selain itu, ada hormon oksitosin yang dapat membantu merangsang kontraksi pada otot-otot rahim sehingga mempermudah persalinan. Hormon ini juga akan membantu memacu kontraksi di pembuluh darah vena yang ada di sekitar payudara ibu, sehingga memacu kelenjar air susu untuk memproduksi ASI.

Menurut data WHO, sebanyak 99\% kematian ibu akibat masalah persalinan atau kelahiran terjadi di negaranegara berkembang (Joseph, 2010). Partus lama rata-rata di dunia menyebabkan kematian ibu sebesar $8 \%$ dan di Indonesia sebesar $9 \%$.

Menurut laporan Puskesmas Klaten Selatan, selama bulan Januari sampai dengan Agustus 2014 tercatat ada 
429 persalinan tanpa memandang paritasnya.

Berdasarkan latar belakang di atas, maka peneliti tertarik mengadakan penelitian tentang "Pengaruh konsumsi sari kurma pada akhir kehamilan terhadar kemajuan persalinan Kala I dan jumlah perdarahan saat persalinan pada primipara di wilayah kerja puskesmas Klaten Selatan".

\section{METODE PENELITIAN}

Penelitian ini adalah penelitian quasi eksperimen dengan rancangan desain static group comparation. Teknik pengambilan sampel menggunakan pendekatan secara purposive sampling, dengan kriteria sampel adalah ibu hamil primipara yang sehat dan tidak mengalami komplikasi, ibu hamil bersedia untuk mengkonsumsi sari kurma setiap hari, ukuran tinggi fundus uteri kurang dari 40 $\mathrm{cm}$, umur kehamilan mulai dari 34 minggu, usia ibu hamil di bawah 35 tahun. Analisa data secara Bivariat, pengujian hipotesis dilakukan mengunakan uji statistik Independent Sample t-test. Penelitian ini menggunakan nilai $\alpha$ sebesar 0,05 atau $5 \%$ dan tingkat kepercayaan penelitian ini $95 \%$.

\section{HASIL PENELITIAN}

Hasil penelitian secara deskriptif disajikan dalam pada tabel dibawah ini :

Tabel 1

Distribusi Frekuensi Berdasarkan

\begin{tabular}{ccc}
\multicolumn{3}{c}{ Umur } \\
\hline Karakteristik & $\mathrm{F}$ & $(\%)$ \\
\hline$\leq 19$ & 2 & 6,6 \\
$20-30$ & 27 & 90,0 \\
$30-40$ & 1 & 3,4 \\
$>40$ & 0 & 0,0 \\
\hline Jumlah & 30 & 100 \\
\hline
\end{tabular}

Tabel 2

Distribusi Frekuensi Berdasarkan Tingkat Pendidikan

\begin{tabular}{ccc}
\hline Karakteristik & F & $(\%)$ \\
\hline SD & 6 & 20,0 \\
SMP & 6 & 20,0 \\
SMA & 17 & 56,7 \\
PT & 1 & 3,3 \\
\hline Jumlah & 30 & 100 \\
\hline
\end{tabular}

Tabel 3

Indikator kemajuan persalinan pada kelompok 1 dan 2

\begin{tabular}{llll}
\hline No & Kemajuan & (Perlakuan) & (Kontrol) \\
\hline 1 & Paling cepat & 1,25 & 1,75 \\
2 & Paling lama & 4,25 & 6,5 \\
3 & Rerata & 2,55 & 3,38 \\
4 & S. Baku & 0,8 & 1,15 \\
\hline
\end{tabular}

Tabel 4

Indikator kemajuan persalinan pada kelompok 1 dan 2

\begin{tabular}{llll}
\hline No & Perdarahan & Perlakuan & Kontrol \\
\hline 1 & Paling sedikit & $120 \mathrm{ml}$ & $225 \mathrm{ml}$ \\
2 & Paling banyak & $225 \mathrm{ml}$ & $250 \mathrm{ml}$ \\
3 & Rerata & $162,17 \mathrm{ml}$ & $186,17 \mathrm{ml}$ \\
4 & S. Baku & 29,61 & 29,76 \\
\hline & Hasil & penelitian & menunjukan
\end{tabular}

bahwa kemajuan persalinan kala I dilihat dari lama mencapai pembukaan lengkap $(10 \mathrm{~cm})$ paling cepat 1,25 jam pada kelompok 1 (perlakuan) dan 1,75 jam pada kelompok 2 (kontrol), sedangkan paling lama 4,25 jam kelompok 1 (perlakukan) dan 6,5 jam kelompok 2(kontrol). Rerata dan simpangan baku yang didapat adalah $2,55+0,8$ jam pada kelompok 1 (perlakukan) dan 3,38 + 1,15 jam pada kelompok 2 (kontrol).

Hasil di atas menunjukkan adanya perbedaan bahwa pada kelompok ibu primipara yang diberikan sari kurma selama masa kehamilan dilihat dari rerata mengalami kemajuan pembukaan yang lebih cepat yakni 2,55 jam dari 3,38 jam 
artinya kelompok 1 (perlakuan) dalam mencapai pembukaan lengkap lebih cepat 0,83 jam (49,8 menit).

\section{PEMBAHASAN}

Kurma mengandung stimulan tertentu yang memperkuat otot-otot rahim dalam beberapa bulan terakhir kehamilan. Hal ini membantu memperkuat kontraksi rahim pada saat persalinan. Kurma adalah buah yang kaya akan nutrisi. Di dalamnya terkandung karbohidrat, fiber, kalsium, kalium, vitamin B kompleks, magnesium, dan zat besi. Pada kurma kering terdapat kandungan $70 \%$ karbohidrat, sedangkan pada kurma basah ada kandungan $60 \%$ karbohidrat dalam bentuk glukosa dan fruktosa. Kedua jenis gula ini tidak berbahaya karena hasil olahan alami. Glukosa dan fruktosa alami ini sangat mudah diserap oleh tubuh. Dan fungsinya adalah untuk menggantikan energi yang hilang. Itulah bagi ibu hamil, energi dari gula yang dihasilkan, bermanfaat untuk menambah kekuatan pada saat persalinan.

Hasil penelitian menunjukan bahwa jumlah perdarahan persalinan kala I dilihat dari banyaknya perdarahan (ml) paling sedikit $120 \mathrm{ml}$ pada kelompok 1 (perlakuan) dan $125 \mathrm{ml}$ pada kelompok 2 (kontrol), sedangkan paling banyak 225 ml kelompok 1 (perlakukan) dan $250 \mathrm{ml}$ kelompok 2 (kontrol). Rerata dan simpangan baku yang didapat adalah $162,17+29,61 \mathrm{ml}$ pada kelompok 1 (perlakukan) dan 186,17 + 29,76 $\mathrm{ml}$ pada kelompok 2 (kontrol).

Kurma mengandung suatu hormon yang sering disebut dengan hormon potuchin, yang menurut para pakar medis, hormon ini berfungsi untuk mengikat rahim dan otot rahim sehingga dapat membantu mengurangi pendarahan pasca melahirkan. Selain itu, ada hormon oksitosin yang dapat membantu merangsang kontraksi pada otot-otot rahim sehingga mempermudah persalinan. Hormon ini juga akan membantu memacu kontraksi di pembuluh darah vena yang ada di sekitar payudara ibu, sehingga memacu kelenjar air susu untuk memproduksi ASI.

Pada uji hipotesis berkenaan dengan kemajuan persalinan kala I didapatkan $\mathrm{t}$ hitung $-3,234$ sedangkan $\mathrm{t}$ tabel pada dk n-2 (58) adalah 2,002 sehingga Ho ditolak karena -3,234>2,002 artinya "ada pengaruh antara konsumsi sari kurma secara teratur pada akhir kehamilan dengan kemajuan persalinan kala I pada primipara di BPM wilayah Klaten Selatan Kabupaten Klaten. Pada jumlah perdarahan didapatkan t hitung 3,131 sedangkan t tabel pada dk n-2 (58) adalah 2,002 sehingga Ho ditolak karena $3,131>2,002$ artinya "ada pengaruh antara konsumsi sari kurma secara teratur pada akhir kehamilan dengan jumlah perdarahan persalinan pada primipara di BPM wilayah Klaten Selatan Kabupaten Klaten.

\section{KESIMPULAN DAN SARAN}

Laju kemajuan persalinan pada primipara di BPM wilayah Klaten Selatan Kabupaten Klaten mengalami perbedaan antara kelompok 1 ibu hamil yang diberikan sari kurma dibanding kelompok 2 yang tidak diberikan sari kurma yang ditunjukkan rerata lama pembukaan kelompok 1 sebesar 2,55 jam dan kelompok 2 sebesar 3,38 jam.

Jumlah perdarahan persalinan pada primipara di BPM wilayah Klaten Selatan Kabupaten Klaten mengalami perbedaan antara kelompok 1 ibu hamil yang diberikan sari kurma dibanding kelompok 2 yang tidak diberikan sari kurma yang 
ditunjukkan banyaknya darah yang keluar dengan rerata $162,17 \mathrm{ml}$ pada kelompok 1 dan 186,17 ml pada kelompok 2 .

Ada pengaruh antara konsumsi sari kurma secara teratur pada akhir kehamilan dengan kemajuan persalinan kala I dengan t hitung -3,234 dan jumlah perdarahan selama persalinan dengan t hitung $-3,131$ pada primipara di BPM wilayah Klaten Selatan Kabupaten Klaten sedangkan t tabelnya ada 2,002.

Saran untuk penelitian ini, hendaknya pada ibu-ibu hamil yang menjelang persalinan dianjurkan dapat mengkonsumsi kurma karena baik untuk selama kehamilannya, persalinannya dan selama menyusui.

Para Bidan di BPM sari kurma dapat dijadikan salahsatu terapi komplementer dalam pelayananya kepada ibu hamil.

\section{DAFTAR RUJUKAN}

Arikunto, S. 2006. Prosedur Penelitian Suatu Pendekatan Praktek, PT. Rineka Cipta: Jakarta.

Chapman,V. (2003) The Midwife's Labour and Birth Handbook. Blackwell Publishing, Oxford

Danuatmaja,B. (2004) Persalinan Normal Tanpa Rasa Sakit. Puspa Swara, Jakarta

Fainstein. 2001. Asuhan Kebidanan Persalinan Dan Kelahiran. EGC: Jakarta.

Frietman. 1998. Mempersiapkan Kehamilan Sehat. Puspa Swara: Jakarta.

Government of Sindh. 2010. Dates Processing Plant :Sindh

Khadem N, et all. 2007. Comparing the Efficacy of Dates and Oxytocin in the Management of Postpartum Hemorrhage. Mashhad University of Medical Science. Mashhad : Iran

Kleini,M. Renfrew,M. \& Neilso, J. 1996. Buku Acuan Dan Panduan Asuhan Persalinan Normal Dan Inisiasi Menyusu Dini: Jakarta.

Kumarawati, E. (2010) Pengaruh Pemberian Pocari Sweat Terhadap Kualitas His Persalinan. Diakses tanggal 15 September 2014. http://isjd.pdii.lipi.go.id/admin/jurnal /11102529.pdf

Manuaba, 1998. Buku Ajar Konsep Kebidanan, Edisi Bahasa Indonesia. EGC: Jakarta.

Mocthar, 1998. Dasar-Dasar Keperawatan Maternitas. EGC: Jakarta.

Nurgiyanto, 2004. Pedoman Riset Praktis. EGC: Jakarta.

Nursalam, 2003. Konsep \& Penerapan Metodelogi Penelitian Ilmu Keperawatan. Jakarta : Media Asculapius.

Saifuddin, A.B. 2002. Buku Acuan Praktis Pelayanan Kesehatan Maternal Dan Neonatal ; Persalinan Normal. Yayasan Bina Pustaka Sarwono Prawirohardjo: Jakarta. 